\title{
Half-ironman induces changes in the kidney function of triathletes
}

\author{
ENRICO F. PUGGINA, DALMO R.L. MACHADO, HUGO TOURINHO FILHO and VALDIR J. BARBANTI
}

Escola de Educação Física e Esporte de Ribeirao Preto, Ribeirão Preto, Av. Bandeirantes, 3900, Monte Alegre, 14040-900 Ribeirão Preto, SP, Brasil

Manuscript received on September 18, 2012; accepted for publication on April 15, 2013

\begin{abstract}
Long duration exercise may lead to the occurrence of urine abnormalities. Aiming to investigate the effects of triathlon training and competition on the renal function, twelve male triathletes $(32.60 \pm 5.10$ years, $175.04 \pm 6.67 \mathrm{~m}, 71.83 \pm 7.42 \mathrm{Kg}$ ) were studied during the 12-week training protocol and after a Half Ironman. Urine was collected in M-1 - beginning of the training season, M-2 - before the competition and M-3 - after the half ironman. Urine $\mathrm{pH}$ was measured using reagent strips, density with a refractometer, proteinuria by Bradford assay, creatinine with a colorimetric assay and blood cells by microscopy. Data were analyzed using Shapiro-Wilk test, One-Way ANOVA and Tukey-Kramer test $(\mathrm{p}<0,05)$. Changes were found after the competition in the protein $(\mathrm{M}-1=7.41 \pm 2.48 ; \mathrm{M}-2=7.57 \pm 3.74 ; \mathrm{M}-3=86.10 \pm 76.21 \mathrm{mg} / \mathrm{mL})$, creatinine $(\mathrm{M}-1=157.66 \pm 41.59 ; \mathrm{M}-2=177.68 \pm 44.46 ; \mathrm{M}-3=316.46 \pm 132.86 \mathrm{mg} / \mathrm{mL})$, erythrocytes $(\mathrm{M}-1=1060.00$ $\pm 0.30 ; \mathrm{M}-2=1142.86 \pm 377.96 ; \mathrm{M}-3=52555.56 \pm 58.65 \mathrm{units} / \mathrm{mL})$ and leucocytes $(\mathrm{M}-1=2375.00 \pm 744.02$; $\mathrm{M}-2=2090.00 \pm 0.50 ; \mathrm{M}-3=5000.00 \pm 2738.60$ units $/ \mathrm{mL}$ ) excretion when compared to the other collection times. These effects are probably due to the exercise-induced modifications in the glomerular membrane and endocrine variables such as anti diuretic hormone, catecholamines and aldosterone.
\end{abstract}

Key words: endurance training, half-ironman, kidney function, urine analysis.

\section{INTRODUCTION}

Endurance capacity is human nature. Resistance against fatigue, adversities and psychological stress are examples of this capacity. Due to its different manifestations in sports, endurance is divided into subtypes, according to muscle mass involved in the exercise, energetic substrates consumption, metabolism, sport specificity and the amount of time spent to execute the activity. Triathlon is a very singular cyclic endurance sport with regards to the training process and competitions.

Long duration of exercise may lead to urine excretion of protein and blood cells due to changes

Correspondence to: Enrico Fuini Puggina

E-mail: enrico@usp.br in glomerular permeability and filtration ratio. Proteinuria is a known effect of exercise and can lead to an excessive protein excretion through urine (Poortmans et al. 1991, Bellinghieri et al. 2008). According to Bellinghieri et al. (2008), after physical effort, the protein excretion ratio can vary from 18 to $100 \%$ depending on the type and intensity of the exercise. Generally, proteinuria is more associated with the intensity than with the duration of the exercise, and as described above, this is a transient effect. The increased protein excretion after physical effort occurs due to increase in the glomerular permeability combined with a partial tubular inhibition to macromolecules in association with changes in the kidney hemodynamic and excretion of electrolytes (Poortmans 1984). 
Studying twenty cyclists after a $102 \mathrm{~km}$ competition, De Paolo et al. (2003) detected an increase in protein excretion, urinary $\mathrm{C}$ peptide after two and half hours competition. The authors concluded that the protein excretion was increased disproportionately compared to peptyde hormones studied and probably this effect (proteinuria) is related to changes in tubular permeability to proteins. In another study, proteinuria and electrolyte imbalances were found in athletes (adventure race participants) after a $100 \mathrm{~km}$ race that lasted 14 hours. Every indicator studied presented transient responses and after six hours rest, most of the indicators returned to physiological concentrations (Gerth et al. 2002).

The exercise-induced proteinuria was also studied in baseball players (Miyai and Ogata 1990), swimmers (Poortmans et al. 1991) and triathletes (Edes et al. 1990), and in all cases, the increased excretion of protein after physical effort returned to physiological condition after a few hours of resting.

Creatinine is a non proteic organic nitrogenous compound produced from creatine dehydration. The formation of this compound occurs mainly in the skeletal muscle when the unused creatine is converted into creatinine and excreted through the urine (Narayanan and Appleton 1980, Levey et al. 1988). Previous studies (Ayca et al. 2006) investigated the acute effects of volleyball practice on kidney clearance through creatinine excretion. They found an increase of the kidney filtration ratio after physical effort, indicating that exercise can induce acute and transient changes in the kidney function and hemodynamic.

Another known effect of exercise is hematuria (Bellinghieri et al. 2008). The presence of erythrocytes in urine can indicate inflammation, infection or trauma in the kidney or urinary tract. Generally, hematuria in athletes is associated with the exerciseinduced increase in kidney blood flow and with the impact of footfall during the race. The prevalence of hematuria seems to be higher in athletes than in non-athletes and this disturbance tends to disappear after a few hours of rest. Similarly to proteinuria, occurrence of hematuria depends on the duration and intensity of the effort, and of the core temperature. Hemolysis, excessive secretion of catecholamines and acidosis are also among the mechanisms that induce the pigment excretion in the urine (Bellinghieri et al. 2008).

These effects have been demonstrated in several athletes performing different sports modalities. Studying 51 athletes who participated in a $100 \mathrm{~km}$ competition that lasted 14 hours and 25', Gerth et al. (2002) found changes in blood and urine biochemical markers, as well as in the red blood cells excreted in urine collected immediately and six hours after the race. By observing the appearance of cells under the microscope, the author concluded that they were from kidney damage and not from the increased capillary permeability due to exercise.

In a case study performed with a mountain biker, the occurrence of hematuria was observed after a long duration competition (Albersen et al. 2006). As in the previous study, the observed exercise effect was attributed to kidney damage, a very unusual event in cyclists. Unlike the study cited above, the occurrence of red blood cells in urine seems to be very common in long distance runners (Ducloux et al. 1999, Kallmeyer and Miller 1993). Similar to hematuria, the presence of leucocytes in urine can indicate glomerular or tubular damage, increased glomerular permeability or inflammation of the urinary tract (Poortmans 1984, Ducloux et al. 1999) and very few studies have been dedicated to investigate the presence of leucocytes in urine due to physical exertion (Richter et al. 2007).

Although many previous studies have contemplated the effects of aerobic training modalities, such results cannot be extrapolated to the triathlon because of its peculiarities. Currently, 
the growing number of practitioners and events, allows the study of the effects of triathlon training and competition.

Another important factor is the lack of published studies on the changes of kidney function of triathletes in real conditions of training and competition, so few studies reflect the effects of training and participation in long distance competitions at ambiental conditions.

The aim of this study was to investigate the effects of triathlon (half ironman) training and competition on renal function in normal subjects using urinary parameters (density, $\mathrm{pH}$, protein and creatinine excretion and blood cells) at the beginning of the training season, as well as before and 30 minutes after a half ironman, with the objective of identifying possible acute renal changes produced by the effort.

\section{MATERIALS AND METHODS}

\section{SUBJECTS}

Twelve male triathletes volunteered to participate in the study. After signing an informed consent, they were submitted to the experimental protocol. The demographic data on the subjects studied, are available in the table I, and all the procedures and methods adopted in this study were approved by the ethics committee of the Faculty of Pharmaceutical Sciences of Ribeirão Preto of the University of São Paulo.

\section{TABLE I}

Sample characteristics ( $N$, age, gender), training experience (years) and performance (time spent during the half ironman) in the half ironman.

\begin{tabular}{c|c}
\hline $\mathbf{N}$ & 12 \\
\hline Age & $32.6 \pm 5.1$ years \\
\hline Gender & Male \\
\hline Height & $175.04 \pm 6.67 \mathrm{~m}$ \\
\hline Body Weight & $71.83 \pm 7.42$ \\
\hline IMC & $24.05 \pm 2.89 \mathrm{~kg} / \mathrm{m}^{2}$ \\
\hline Training experience & $6.5 \pm 4.9$ years \\
\hline Performance & 5 hours $07 \mathrm{~min} \pm 38 \mathrm{~min}$ \\
\hline
\end{tabular}

TRAINING PROTOCOL

The athletes followed a periodized twelve week training protocol with $80 \%$ of continuous training in the average intensity of the lactate threshold and $20 \%$ of interval training to participate in the Pirassununga Air Force Academy Half Ironman (1.9 km swimming, $90 \mathrm{~km}$ cycling and $21 \mathrm{~km}$ running), performed every year in Pirassununga, Brazil. The training program lasted 12 weeks of increased mileage: in M-1 (beginning of the training season) the average distance completed by the athlete was $213.8 \mathrm{~km} /$ week (including swimming, cycling and running) and $248.1 \mathrm{~km}$ in M-2 (a week before the competition).

\section{URINE COLLECTION AND ANALYSIS}

Urine was collected 4 hours after the last void in three instances: in the beginning of the training season (M-1), before the competition (M-2), and 30 minutes after completing the half ironman (M-3). The collection was carried out after asepsis of the genital organ, and the urine sample was immediately refrigerated $\left(2-8^{\circ} \mathrm{C}\right)$ and transported to the laboratory for analysis.

The urine $\mathrm{pH}$ was determined using reagent strips (Urofita 10DL, Biobrás Diagnósticos ${ }^{\circledR}$, Belo Horizonte, Brazil). Density was measured using a manual refractometer (Uricon N, Atago $^{\circledR}$, Tokyo, Japan). Protein content was determined following the Bradford method (Bradford 1976). Total protein content was obtained using a calibration curve multiplied by the dilution factor and expressed in $\mathrm{mg} / \mathrm{dL}$.

The urinary creatinine concentration was determined using a colorimetric assay (Human do Brasil ${ }^{\circledR}$, Itabira, Brazil). In brief, urine samples were added to reagents provided in the assay and the mixture was incubated for 10 minutes at $37^{\circ} \mathrm{C}$. Subsequently, optical density was determined for each sample using a spectrophotometer (Ultrospec $3100 \mathrm{Pr}$, Amersham Pharmacia Biotech $^{\circledR}$, Piscataway, USA) and the creatinine concentration was calculated 
by comparing the samples to a standard curve with results being expressed in $\mathrm{mg} / \mathrm{dL}$. Finally, the urinary cell count (erythrocytes and leukocytes) in the urinary sediment was performed using a hemocytometer (light microscopy).

\section{STATISTICS}

Results were analyzed using GraphPad and Prism $^{\circledR}$ (La Jolla, GraphPad Software, USA). Data were firstly analyzed by Shapiro-Wilk normality test followed by One-Way ANOVA and Tukey-

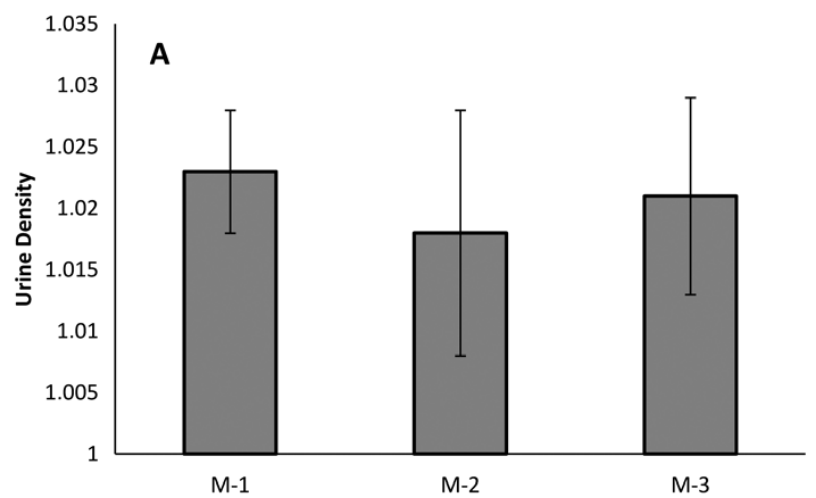

Kramer test to determine differences between groups (level of significance $\mathrm{p}<0.05$ ).

\section{RESULTS}

The expectancy of measuring urine density and $\mathrm{pH}$ was to identify evidences of dehydration and excretion of acid metabolites during the training season and competition. Figure 1 shows the results obtained for urine density (A) and $\mathrm{pH}(\mathrm{B})$. In both cases, no differences were found when $\mathrm{M}-1, \mathrm{M}-2$ and M-3 were compared.

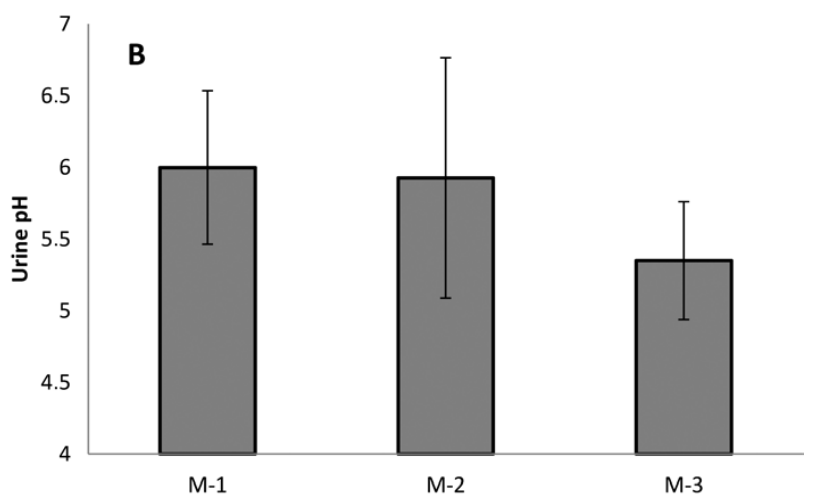

Figure 1 - Urine density (1A) and urine $\mathrm{pH}(1 \mathrm{~B})$ at beginning of the training season (M-1), before (M-2) and after the competition (M-3).

Unlike the data obtained for urine density and $\mathrm{pH}$ (Figure 1), excretion of protein and creatinine revealed a significant increase after the competition (Figure 2A). For protein excretion, the values found reached $86.10 \pm 76.21 \mathrm{mg} / \mathrm{dL}$ in $\mathrm{M}-3$, an increase of approximately $1000 \%$ compared to $\mathrm{M}-1$ and $\mathrm{M}-2$ $(p=0.003)$, in which collections were made at rest condition. Protein excretion is a strong indicator of kidney damage in people diagnosed with acute or chronic renal disease (Guh 2010), but in the case of athletes, it indicates changes in the glomerular permeability to proteins or renal tract damage due to exercise, and is described as a transient effect (Clerico et al. 1990, Edes et al. 1990, Ayca et al. 2006, Bellinghieri et al. 2008).

For the creatinine results (Figure 2B), in M-3 $316.46 \pm 132.86 \mathrm{mg} / \mathrm{dL}$ was found, an increase of $100.72 \%$ compared to $\mathrm{M}-1$ and $78.1 \%$ in relation to $\mathrm{M}-2(\mathrm{p}=0.0028)$. Urine creatinine excretion is related to the muscle mass and indicates the creatine metabolism in the skeletal muscle (Levey et al. 1988). This metabolite is excreted in constant concentrations in urine and is commonly used to measure the renal filtration ratio, therefore, when the creatinine excretion is increased, it indicates the increase of kidney blood flow in healthy subjects (Narayanan and Appleton 1980).

In the case of leukocytes, the physiological occurrence in urine is 5 to 10 in each field of the neubauer chamber, and the neutrophils are the most common. Increased amounts of leukocytes in urine can indicate inflammation, infection or traumatic damage in the urinary tract.

In this study, both erythrocytes and leucocytes (Figure 3) were observed. In both cases, the cell count in urine was increased after the competition. 

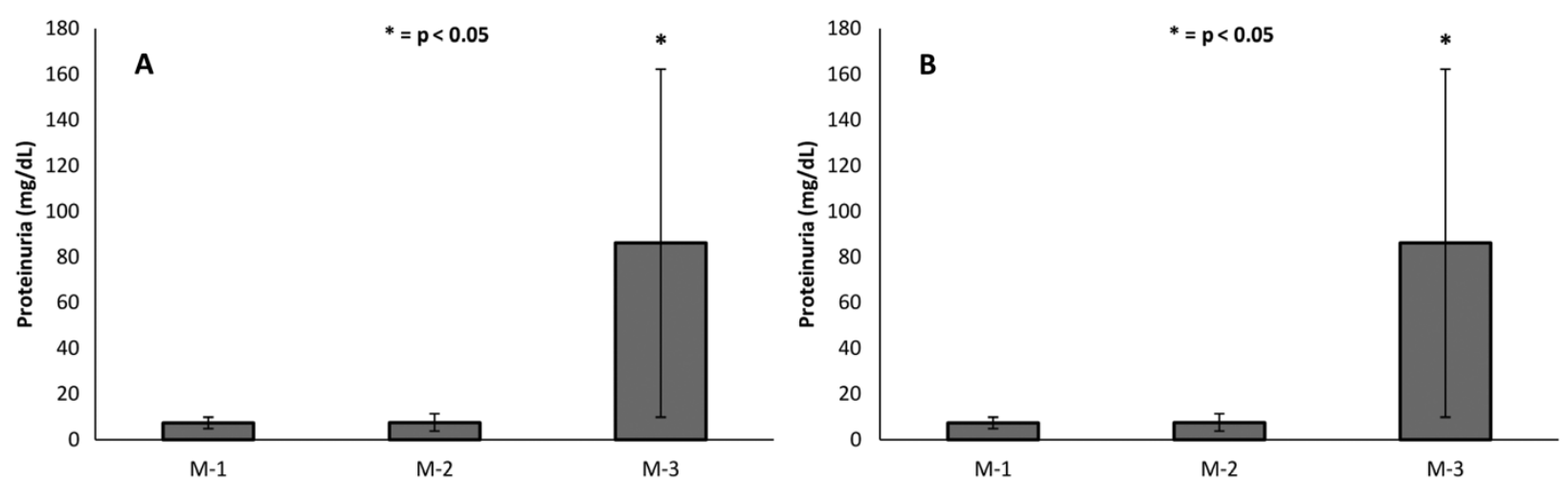

Figure 2 - Proteinuria in $\mathrm{mg} / \mathrm{dL}(2 \mathrm{~A})$ and creatinine concentration in $\mathrm{mg} / \mathrm{dL}(2 \mathrm{~B})$ at beginning of the training season (M-1), before $(\mathrm{M}-2)$ and after the competition $(\mathrm{M}-3){ }^{*}=\mathrm{p}<0.05$.

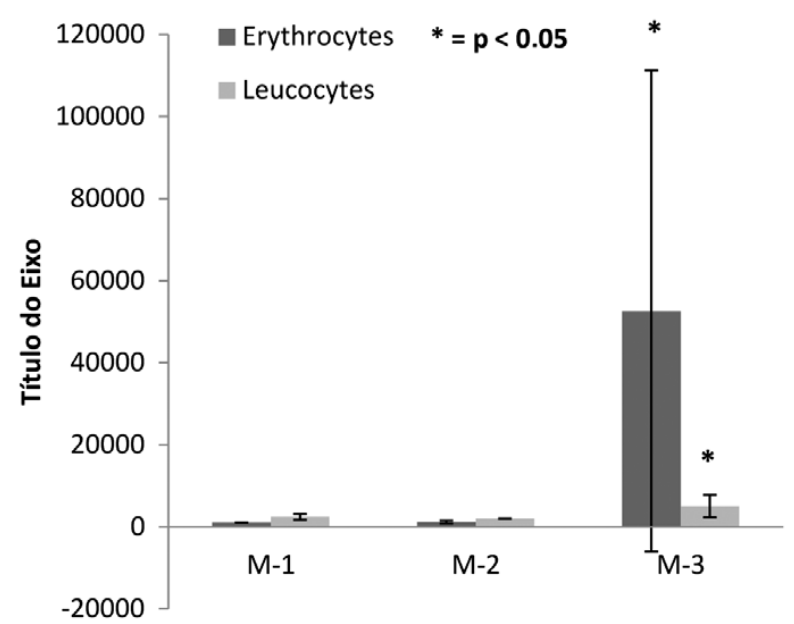

Figure 3 - Erythrocytes and leucocytes count in units $/ \mathrm{mL}$ in the beginning of training season (M-1), before the competition (M-2) and after the competition (M-3), $*=p<0.05$.

For the red blood cells, the increase was approximately $5.000 \%$ when M-3 was compared to the other times of collection $(p=0.0106)$, and in the case of leucocytes, the increase was $110 \%$ when compared to $\mathrm{M}-1$ and $150 \%$ when compared to $\mathrm{M}-2(\mathrm{p}=0.0038)$.

\section{DISCUSSION}

In this study, no differences were detected in urine density and $\mathrm{pH}$ in the three times of collection. The expectancy when measuring the urine density and $\mathrm{pH}$ was to detect evidences of dehydration mainly 30 minutes after the competition. According to
Clerico et al. (1990), the kidney blood flow is reduced during physical effort and this effect is related to the intensity of the exercise. This effect is due to the activity of the sympathetic nervous system and catecholamine release, inducing the reductions in the kidney blood flow and the ratio of the glomerular filtration rate. In the case of dehydration due to exercise, the glomerular filtration ratio can be further reduced.

Together, urine density and $\mathrm{pH}$ could indicate dehydration and acidic metabolites produced during the competition. However, the expectancy for both indicators was not confirmed and the athletes did not reveal any signs of dehydration and acidic metabolites excretion. These results confirm the findings of previous studies (Farber et al. 1991, Hausswirth and Lehenaff 2001) where no evidences of dehydration was found after a long distance triathlon (Pastene et al. 1996).

According to Bellinghieri et al. (2008), in normal people, the excretion of protein in urine is $80 \mathrm{mg} / \mathrm{mL}$ in 24 hours and values above $100 \mathrm{mg} / \mathrm{mL}$ in adults can reflect kidney disease. Generally, sixty percent of the protein in urine is filtered before excretion and forty percent is excreted into tubules. The glomerular permeability to the protein is limited by molecular weight and size and electrostatic interactions between some circulating molecules and components of the glomerular membrane. 
In physiological conditions, proteinuria consists of plasmatic proteins (albumin, transferring, secretory $\operatorname{IgA}$, urochinasis and others) and the prevalence of proteinuria can be due to glomerular or tubular changes. However, same factors can lead to functional proteinuria such as pregnancy, fever and physical activity (Irving et al. 1986). Exercise induced proteinuria was reported in military officers submitted to intense training, i.e. volleyball players and runners (Poortmans et al. 1989). The study of (Clerico et al. 1990) indicates that albuminuria furnishes a greater contribution to the exerciseinduced proteinuria and the probable origin of the increased excretion of protein is glomerular and tubular, and is reversible.

Similar to other literature, this study shows that increased proteinuria after physical effort was observed after a half ironman and the likely sources were the changes in the glomerular permeability and the plasmatic proteins due to the haemolysis and endocrine factors during the exercise (Edes et al. 1990, Poortmans et al. 1991, Gerth et al. 2002, De Paolo et al. 2003).

Creatinine is derived from creatine metabolism and its turnover in healthy men is constant due to the total muscle mass that corresponds to almost $100 \%$ of the storage of creatine in the body (Banfi et al. 2009). Urine creatinine is commonly used as an indicator of kidney function, indicating the glomerular filtration ratio because it is released in a very constant quantity during the day (Narayanan and Appleton 1980).

Our results suggest an increase of the glomerular filtration ratio during the half ironman and are in accordance with the consulted literature (Poortmans 1984, Levey et al. 1988, Ayca et al. 2006), that found increased creatinine excretion in volleyball players and other sports. These findings suggest that exercise induces changes in the kidney blood flow and modifies the renal function during exercise, increasing the glomerular filtration ratio during aerobic and anaerobic physical activities.
The fact that very similar results were found in different sports suggests the need for more studies in order for this phenomenon to be understood.

In the case of blood cells, the excretion of erythrocytes in urine can be attributed to changes in the glomerular permeability due to exercise, as well as kidney and urinary tract damage caused by successive strides during the race. In physiological conditions, the occurrence of red blood cells in urine is 3 to 10 , in each field of the neubauer chamber. The hematuria commonly indicates inflammation, infection or traumatic damage of the kidneys or urinary tract. Strenuous exercise can lead to mild hematuria, which is very common in long distance runners and is commonly associated with increased kidney blood flow due to exercise.

The morphology of the erythrocytes can indicate the source of the cells eliminated in the urine, and can help as a differential diagnosis of hematuria. Erythrocytes in their usual spherical shape indicate hematuria originated in the lower urinary tract, and crenated (irregular shape) red blood cells suggest glomerular origin. As per our knowledge this is the first study where the excretion of blood cells were studied in triathletes. In the consulted literature, this exercise effect is transient and is not associated with pathologies, once it was detected just after physical effort (Poortmans 1984, Irving et al. 1986, Kallmeyer and Miller 1993, Bellinghieri et al. 2008).

For the leucocytes, the excretion of these cells seems to follow the same dynamics of the erythrocytes after physical effort, in other words, the excretion of leucocytes in urine can be due to the increased kidney blood flow, kidney and urinary tract damage, glomerular filtration ratio and glomerular permeability due to exercise (Poortmans 1984).

During the training program (M-1 and M-2) when the collections were made after 24 hours rest, no differences were found in the excretion of leucocytes while an increase of $150 \%$ was found after the half ironman. These results 
suggest that the increase of excretion of the leucocytes was due to hemodynamic changes in the kidney blood flow and endocrine variables as aldosterone and anti-diuretic hormone during the race that led to changes in the glomerular permeability (Poortmans 1984). Similar to the previous indicator, this seems to be the first study that showed the appearance of leukocytes after strenuous exercise.

Our results illustrate that long term effort leads to the occurrence of changes in the function of the urinary system. Symptoms such as proteinuria and excretion of blood cells are commonly related to chronic kidney disease such as glomerulonephitis and glomerulosclerosis. However, in the case of this study, the results may be interpreted as acute effects of competition, due to the results observed on previous research with cyclists (De Paolo et al. 2003), adventure racers (Gerth et al. 2002) and baseball players (Miyai and Ogata 1990), and can disappear after 6 to 8 hours rest following the effort. In this sense, changes in renal function produced by half ironman are probably not harmful to the athlete's health due to their transitory nature. The athletes and coaches need to be aware of the volume and intensity of training, avoiding the chronicity of these undesirable symptoms in triathlon athletes, protecting them from possible complications of renal tract and function.

From the results of this study we conclude that for the measurements taken in urine, changes were only found following the half ironman with regards to the excretion of protein, creatinine, erythrocytes and leucocytes and these effects are probably due to the exercise-induced modifications in the glomerular membrane permeability and to the endocrine variables such as anti-diuretic hormone, catecholamines and aldosterone. In the future, after further investigations, these indicators could be used to control the stress imposed by exercise in an attempt to find noninvasive methods of load control during the training season.

\section{ACKNOWLEDGMENTS}

We would like to acknowledge the Conselho Nacional de Desenvolvimento Científico e Tecnológico (CNPq) for the financial support to conduct this project.

\section{RESUMO}

O exercício de longa duração pode levar ao aparecimento de anormalidades urinárias. Com o objetivo de investigar os efeitos do treinamento de resistência e de um meio ironman na função renal de triatletas, doze atletas (32.60 \pm 5.10 anos, $175.04 \pm 6.67 \mathrm{~m}, 71.83 \pm 7.42 \mathrm{Kg}$ ) foram estudados durante 12 semanas de treinamento e após uma prova de meio Ironman. A urina foi coletada em M-1 - início do programa de treinamento, M-2 - antes da competição M-3 - depois do meio ironman. O pH urinário foi mensurado através de tiras reagentes, a densidade com um refractômetro, a proteinuria pelo ensaio de Bradford, a creatinina por método colorimétrico e a contagem de células por microscopia. Os dados foram analisados através dos testes de Shapiro-Wilk, One-Way ANOVA e TukeyKramer $(\mathrm{p}<0,05)$. Foram encontradas alterações após a competição para proteinúria $(\mathrm{M}-1=7.41 \pm 2.48$; $\mathrm{M}-2=$ $7.57 \pm 3.74 ; \mathrm{M}-3=86.10 \pm 76.21 \mathrm{mg} / \mathrm{mL}$ ), creatinina (M$1=157.66 \pm 41.59 ; \mathrm{M}-2=177.68 \pm 44.46 ; \mathrm{M}-3=316.46 \pm$ $132.86 \mathrm{mg} / \mathrm{mL})$, eritrócitos (M-1= $1060.00 \pm 0.30 ; \mathrm{M}-2=$ $1142.86 \pm 377.96 ; \mathrm{M}-3=52555.56 \pm 58.65$ units $/ \mathrm{mL})$ e leucócitos (M-1=2375.00 $\pm 744.02 ; \mathrm{M}-2=2090.00 \pm 0.50$; $\mathrm{M}-3=5000.00 \pm 2738.60$ units $/ \mathrm{mL}$ ) quando comparados com outros momentos de coleta. Esses efeitos são provavelmente resultado de modificações da membrana glomerular decorrentes do exercício e a variáveis endócrinas como $\mathrm{ADH}$, catacolaminas e aldosterona.

Palavras-chave: treinamento de resistência, meio-ironman, função renal, análise da urina.

\section{REFERENCES}

Albersen M, Mortelmans L And BAERT J. 2006. Mountainbiker's Hematuria: A Case Report. Eur J Emerg Med 13(4): 236-237.

Ayca B, Sener A, Apikoglu Rabus S and Oba R. 2006. The Effect of Exercise on Urinary Gamma-Glutamyl Transferase and Protein Levels of Volleyball Players. J Sports Med Phys Fitness 46(4): 623-627. 
BANFi G, Del FABBro M AND LiPPi G. 2009. Serum Creatinine Concentration and Creatinine-Based Estimation of Glomerular Filtration Rate in Athletes. Sports Med 39(4): 331-337.

Bellinghieri G, SAVICA V And SANTORo D. 2008. Renal Alterations During Exercise. J Ren Nutr 18(1): 158-164.

BRADFORD M. 1976. A rapid and sensitive method for the quantitation of microgram quantities of proteins utilizing the principle of protein dye binding. Anal Biochem 72: $248-254$

Clerico A, Giammattei C, Cecchini L, Lucchetti A, Cruschelli L, Penno G, Gregori G and Giampietro O. 1990. Exercise-Induced Proteinuria in Well-Trained Athletes. Clin Chem 3(36): 562-564.

De Palo e, Gatti R, Lancerin F, De Palo C, Cappellin E, SoldÀ G AND SPINELla P. 2003. Effects of Acute, Heavy-Resistance Exercise on Urinary Peptide Hormone Excretion in Humans. Clin Chem Lab Med 41(10): 13081313.

Ducloux D, Lemouel A AND Chalopin J. 1999. Renal Papillary Necrosis in a Marathon Runner. Nephrol Dial Transplant 14(1): 247-248.

Edes T, Shah J AND Thornton JR W. 1990. Spontaneous Decline in Exercise-Induced Proteinuria During a 100mile Triathlon. South Med J 83(9): 1044-1046.

FARBER H, SchaEFER E, FrANEY R, GRIMALDI R AND HILl N. 1991. The Endurance Triathlon: Metabolic Changes After Each Event and During Recovery. Med Sci Sports Exerc 23: 959-965.

GERTH J, OTT U, FÜNFSTÜCK R, BARTSCH R, KEIL E, SCHUBERT K, HÜbscher J, Scheucht S And SteIn G. 2002. The Effects of Prolonged Physical Exercise on Renal Function, Electrolyte Balance and Muscle Cell Breakdown. Clin Nephrol 57(6): 425-431.
GUH J. 2010. Proteinuria versus albuminuria in chronic kidney disease. Nephrol 15(2) 53-56.

HAUSSWIRTH C AND LehENAFF D. 2001. Physiological Demands of Running During Long Distance Runs and Triathlons. Sports Med 31: 679-689.

IRVING R, NoAKes T, IRVING G AND VAN ZYL-SMIT R. 1986. The immediate and delayed effects of marathon running on renal function. J Urol 136: 1176-1180.

Kallmeyer J AND Miller N. 1993. Urinary Changes in Ultra Long-Distance Marathon Runners. Nephron 64(1): 119-121.

Levey A, Perrone R And Madias N. 1988. Serum Creatinine and Renal Function. Annu Rev Med 39: 465-490.

MiYAi T AND OGATA M. 1990. Changes in the Concentrations of Urinary Proteins After Physical Exercise. Acta Med Okayama 44(5): 263-266.

NARAYANAN S AND APPLETON H. 1980. Creatinine: A Review. Clin Chem 26(8): 1119-1126.

PASTENE J, GeRmain M, AlleVARd A, GHARIB C AND LACOUR J. 1996. Water Balance During and After Marathon Running. Eur J Appl Physiol Occup Physiol 73: 49-55.

PoORTMAnS J. 1984. Exercise and Renal Function. Sports Med 1(2): 125-153.

Poortmans J, Engels M, SEllier M AND LEClerCQ R. 1991. Urine Protein Excretion and Swimming Events. Med Sci Sports Exerc 23(7): 831-835.

POORTMANS J, RAMPAER L AND WOLFS J. 1989. Renal protein excretion after exercise in man. Eur J Appl Physiol Occup Physiol 58: 476-480.

Richter S, BETZ S AND GeIGER H. 2007. Severe Hyponatremia, Pulmonary and Cerebral Edema in an Ironman Triathlete. Deutsche medizinische Wochenschrift 132: 1829-1832. 